\title{
The long-term Labour Shortage. The Economic Impact of Population Transition and Post-industrialism on the OECD Countries: the Nordic Case
}

\author{
PERTTU SALMENHAARA, Lic. Soc.Sc, Doctoral Student \\ University of Helsinki, Finland
}

\begin{abstract}
This paper presents a survey of results about studies on ageing. The data is collected from population projections by the United Nations, OECD, the European Union and the Eurostat.The research question is how population ageing affects the percentage of the working age population in the OECD. Special focus countries are the Nordic countries. The method is to collect together comparable data from these previous studies. The results imply that from 2005 to 2050 the number of the elderly in relation to the working-age population is projected to increase radically. Most "advanced" national economies are likely to have problems in providing elderly care services and pensions. In addition, post-industrialisation and ethnic discrimination add to the problem by excluding a fair share of the working-age population from the labour market.
\end{abstract}

Keywords: population ageing, 2005-2050, societal and macro-economic impacts, OECD, Nordic countries

\section{The long-term labour shortage}

Population ageing is currently (2008) a highly topical issue in the OECD countries, ${ }^{1}$ both scientifically and politically. The scientific interest arises from the macro-scale impact that ageing is projected to have on the national economies and social cohesion. The political interest arises from the related negative impact on dependency ratios and public finance. The concern over this has fed scientific research into the subject, especially the compiling of demographic population projections and immigration research. Foreign immigration is suggested to be a crucial constraint in tackling challenges brought about by an ageing workforce. Demographic projections have been made by national statistical offices, the United Nations, the OECD and the European Union (Eurostat). A related issue is how efficiently the shrinking workforces are used. This theme is linked to the study of post-industrialism and labour mismatch. The basic

\footnotetext{
${ }^{1}$ OECD refers to Organisation for Economic Cooperation and Development. See www.oecd.org.
} 
premise of this account is that the workforce is used inefficiently because it does not have the skills that employers demand. A benchmark study in this tradition is Daniel Bell's "The Coming of the Post-Industrial Society (Bell 1999 [1973]). That study has had a huge impact on later studies about the labour market and employment.

This paper complements previous research in two ways: firstly by pulling together their main results and suggestions, and secondly, by applying these results especially to how the working-age population can be expected to decrease in the Nordic countries.

\section{Population ageing decreases the share of the working- age population}

According to population projections (OECD 2007, 30; ${ }^{2} \mathrm{UN}$ projections: United Nations 2002; 2007; UNFPA 1999; European Commission 2002; 2007; Eurostat 2006a; 2006b), the working-age population in the OECD area will decline substantially by 2020. During that time, age cohorts that enter working age are smaller than age cohorts that exit that age (OECD 2007, 30). The large size of the exiting age cohorts is caused by a huge peak in birth rates after the Second World War (ibid.), since when, birth rates in the Western countries have declined to a low level. Age cohorts that were born back in the 1940's and 1950's, often called the baby boomers, are now reaching their 60's and exiting the working age. This distorts the age structure of the national populations: without determined population policy, the share of the working-age population is expected to decrease while the share of the elderly population will increase like shown in figure one below. The old-age dependency ratio is defined by the number of the elderly population in relation to the number of working age population. In the countries that the United Nations (2006) classifies as economically advanced the old-age dependency ratio is projected to increase by some two hundred fifty percent during the hundred years from 1950 to 2050 .

The size of the total population in the OECD is likely to decline sharply after this, when the baby boomers reach their 80's and 90's (ibid. 29-33, especially p. 30-31), the death rate will increase, while the birth rate in these countries is likely to remain low (UNFPA 1999). ${ }^{3}$

The population ageing and decline are best described using the demographic concept of population transition. Population transition refers to a macro scale demographic process where the size of the population declines because of changes in the birth rate and the death rate. During the process, also the average age of the population increases. The population transition has four distinct phases and all countries and areas go through these. The economically advanced areas of the world are currently in a phase where

\footnotetext{
${ }^{2}$ The OECD's report “International Migration Outlook" follows the OECD's previous SOPEMI reports; the only difference is the title of the reports. The 2007 edition is the first one with the new title.

${ }^{3}$ This is highly likely however not certain.
} 
both birth rates and death rates are low, the average age of the population is high and the average life expectancy is also high. However, the size of the population remains stable until the high life expectancy results in large elderly age cohorts. Then, the death rate increases and the size of the population declines. ${ }^{4}$

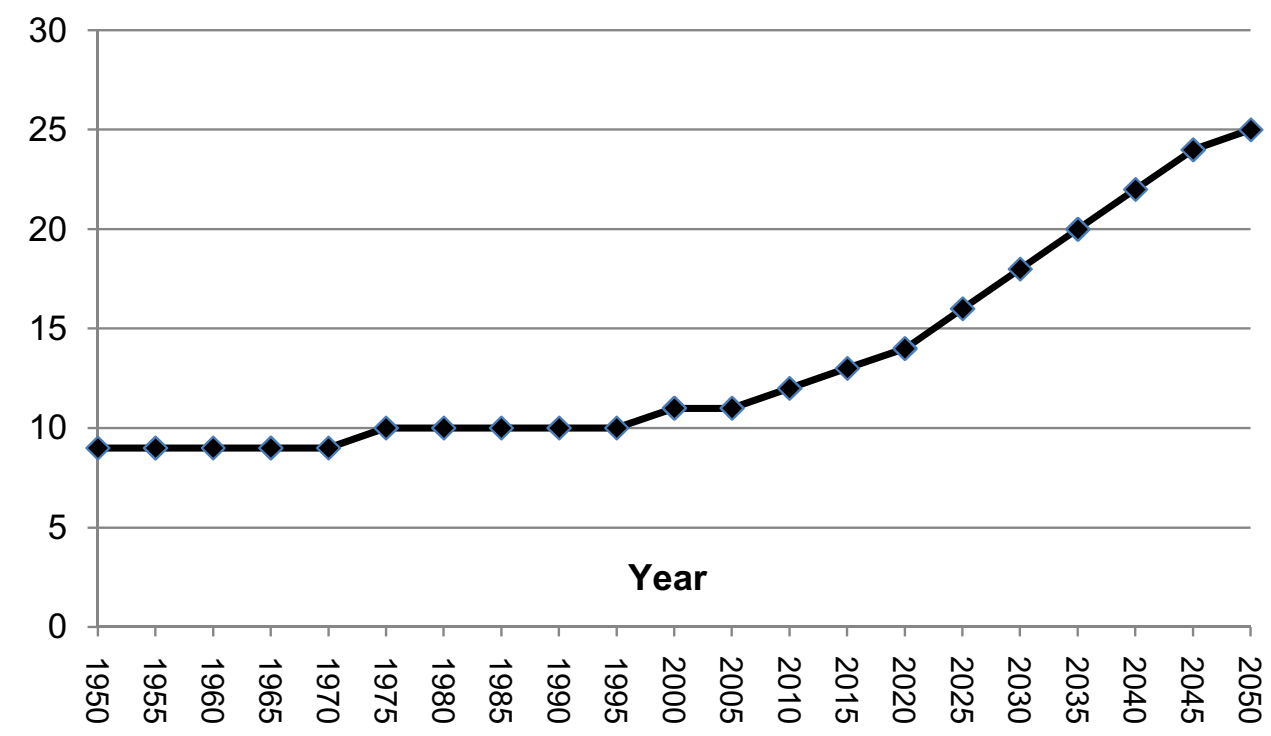

Figure 1. Old-age dependency ratio in the "advanced" economies between 1950 and 2050, according to the United Nations (2006).

Ageing of the population decreases availability of labour, but unlike in the case of similar kinds of previous declines in the OECD countries, the elderly age groups continue to consume at high levels during later life (OECD 2007, 30-31). This consumption (namely pensions and social and health care services) should be produced by, and paid for, an ever-diminishing number of working-age people (ibid; on Europe, United Nations 2007; European Commission 2007). Until recently elderly non-working-age people have not consumed at this level and thus similar declines have not been this problematic.

The figure below shows the OECD's evaluation of how the percentage of workingage population in the OECD countries would develop until the year 2015 without any immigration. According to the projection, between 2010 and 2015, in most countries there would be some natural increase in the number of the working-age population, but already between 2010 an 2015, the shares decline considerably and between 2010 and 2015, the declining trend will continue. Population declines can therefore be expected, but even before this, the old age dependency ratio will steadily worsen.

${ }^{4}$ Most countries in the world are however still in an earlier phase of the transition in which the size of the population increases rapidly. The death has declined e.g. because of good health care, but the birth rate is still high. 


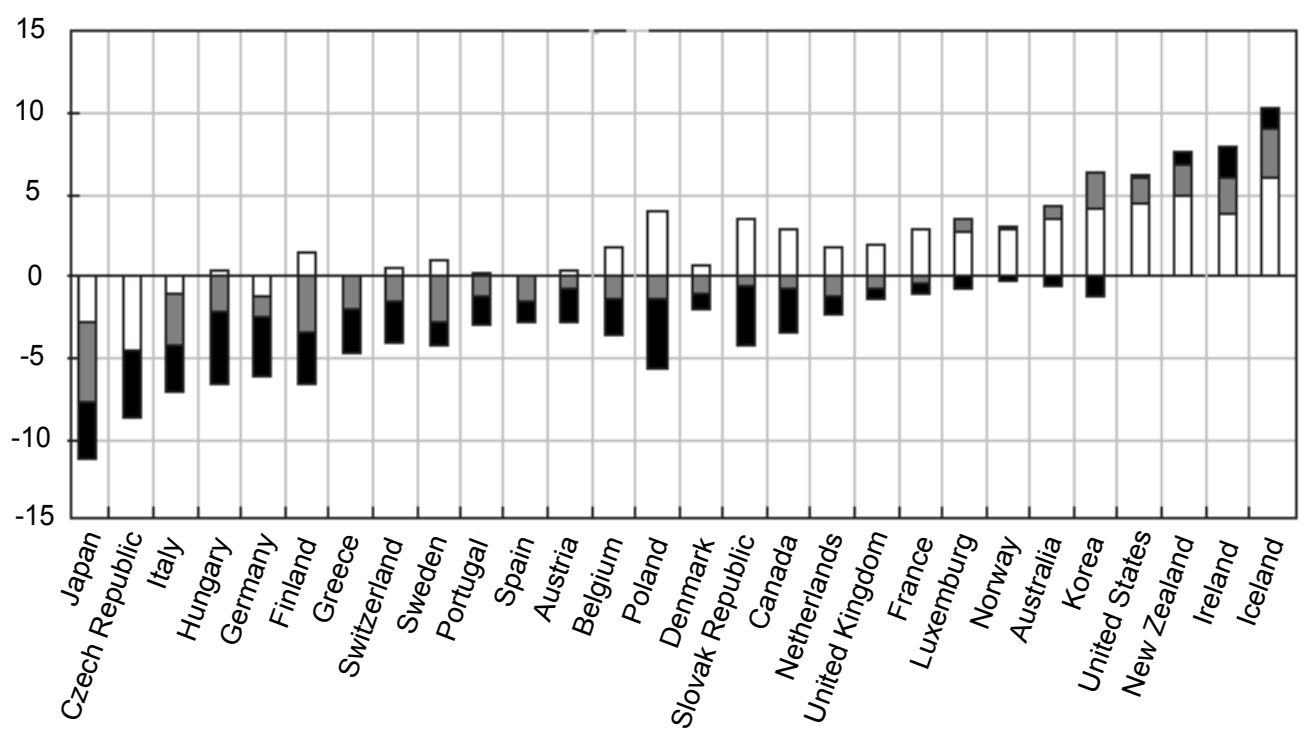

Figure 2. Projected development of the percentage of the working age population in some OECD countries, 2005-2025 (OECD 2007, 31). The middle line is the zero line. The described changes range from minus five to plus twenty percent of the total resident population (2005).

In the Nordic countries, the size of the working-age population will remain stable between 2005 and 2010, but between 2010 and 2015, Sweden and Finland will be among countries within the OECD in which the decline is most rapid (ibid.). Considering that Sweden has received by far the most immigration of the Nordic countries for some decades, this may seem surprising. Immigrants are usually younger than the native population, and therefore Sweden, as the Nordic country that has received by far most immigrants (figure two), should have better age structure than the other Nordic countries. However, this is not the case: despite high numbers of immigrants, Sweden's age structure is in some ways as bad as if there had not been any immigration at all. This is, because the largest immigrant group in Sweden are Finns, and most of those Finns belong to the highest age cohorts themselves. Around the 1970s some 250,000 Finns migrated to Sweden due to migration push factors - mainly because of oversupply of labour (Karisto, Takala \& Haapoja 1998, 58). This large-scale migration shows in net migration statistics as a negative peak for Finland, and as a positive peak for Sweden (figure 3). The same can be seen in the way in which Nordic immigration to Sweden peaked substantially in 1969 and 1970: in the early 70's, the numbers almost doubled and then returned to the previous level (Knocke 2000, 223). The Finnish situation is almost the complete opposite. 


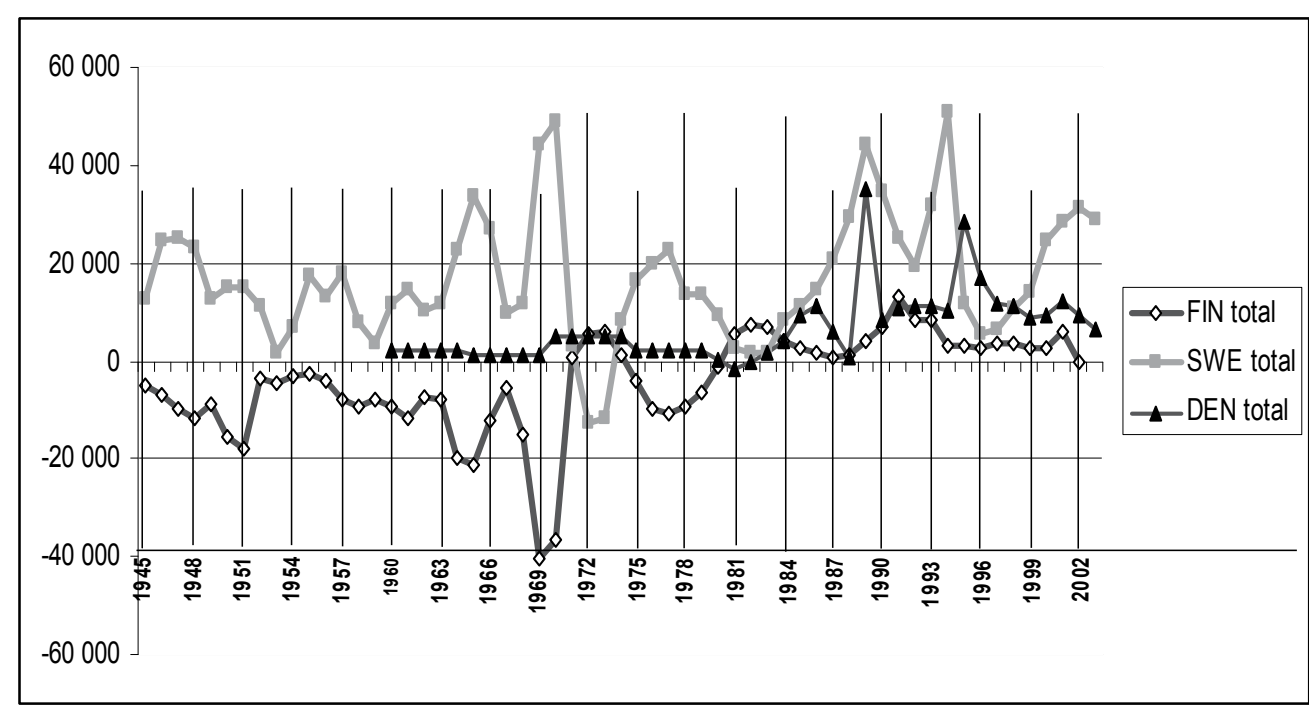

Figure 3. Annual net migration: Sweden, Denmark and Finland 1945-2003, including all foreign countries. Sources: Statistics Finland, Statistics Sweden, Eurostat. Numbers for Denmark between 1960-1979 are 5-year averages.

In Sweden, the annual level of immigration ${ }^{5}$ is currently sufficient to keep the population from declining (OECD 2007, 32); keeping immigration at this level should also be enough to keep the age structure steady. However, in Finland current levels of foreign immigration are too low to keep the working-age population from declining (ibid.). The size of the working-age population does not however, tell the full story, because the labour may not be efficiently used. One of the reasons for inefficient use of labour is a mismatch between the supply and demand. This issue is discussed below.

\section{Mismatch between supply and demand makes the problem worse}

The decline in the size and proportion of the working-age population does not tell the whole story, because not all working-age people are employed. Whereas the decreasing share of the working-age population places a burden on the economic dependency ratio, the fact that even out of this group, only a part is officially employed, increases that burden.

Several reasons have been put forward as to why workers and available jobs do not always overlap and the simultaneous unemployment and labour shortage that results. Firstly, the social capital theory suggests that job seekers and vacancies do not always meet due to information deficit. These two parties would simply not have enough information about each other so that job seekers apply for the right jobs at the right

\footnotetext{
${ }^{5}$ In Sweden, the "sufficient" annual number of immigrants is between 52 and 54 thousand, depending on projection (OECD 2007, 35).
} 
time (Granovetter 1983; 1995 [1974]). Another explanation is provided by the theory of post-industrialism (Bell 1999 [1973]). It suggests that mismatch between the demand for and supply of labour exists mainly because job seekers do not have the demanded skills.

According to Bell's (1999, xv - xii) original definition A post-industrial society is one based on the production of information, rather than on the production of material goods (as in industrialism). According to those who favour this concept, we are currently experiencing a series of social changes as profound as those which initiated the industrial era some two hundred years ago (Giddens 1997, 584). The idea goes that workers' skills would become out-dated in the process and that would cause unemployment. The original definition by Bell (1999) stresses that the new forms of production do not only include information production, but also production of service (1999, xxiv). Human capital -based production is more labour-intensive than industrial work, and thus one worker is able to produce more end products with the same amount of work. In short: less workers, more output, or like Penninx and Roosblad $(2000,189)$ put it, "[c]apital-intensive, highly productive processes demanded better educated but fewer workers". For critical commentary, Beck 2000, 40-41.

This necessitates economic investment in the education of workers in order to direct them towards to the more productive branches of labour. The way in which postindustrialism changes the demand for labour, is empirically described in table 1 below. It shows that in several post-industrial countries, the more formal education a person has, the more likely he is to find employment. ${ }^{6}$

Thus, in economies where the working-age populations are shrinking, there is a need to make better use of the existing labour resources. However, the post-industrial hypothesis suggests that the demand for labour has changed so that the population does not have the necessary education and other credentials for the post-industrial economy. This would explain why a fair share of the working-age population would be either unemployed or over-qualified, this has a particularly pronounced impact in the case of the baby boom generation.

${ }^{6}$ Of the Nordic countries; no data on Iceland was available. 
Table 1. Unemployment by level of education in some OECD countries.

\begin{tabular}{|l|c|c|c|}
\hline & $\begin{array}{c}\text { Low } \\
\text { education } \\
\text { (ISCDE 0/1/2) }\end{array}$ & $\begin{array}{c}\text { Medium } \\
\text { education } \\
\text { (ISCDE 3/4) }\end{array}$ & $\begin{array}{c}\text { High } \\
\text { education } \\
\text { (ISCDE 5/6) }\end{array}$ \\
\hline Denmark & 7,7 & 4,3 & 3,9 \\
Finland & 18,7 & 10,3 & 4,3 \\
Norway & 8 & 3,6 & 2,9 \\
Sweden & 8 & 5,3 & 2,9 \\
Australia & 11,7 & 4,8 & 1,6 \\
Austria & 8,6 & 3,8 & 2,2 \\
Belgium & 10 & 6,8 & 3 \\
Canada & 11,8 & 7,7 & 4,6 \\
Czech Republic & 24 & 7,2 & 2,2 \\
France & 12,2 & 7,9 & 5,8 \\
Germany & 15,6 & 10,4 & 4,4 \\
Hungary & 12,5 & 5,4 & 1,8 \\
Ireland & 7,3 & 3,7 & 2,2 \\
Netherlands & 3,3 & 1,8 & 1,5 \\
New Zealand & 10,9 & 6,9 & 3,3 \\
Poland & 30,4 & 20,4 & 7,4 \\
Portugal & 6,7 & 6,4 & 4,6 \\
Spain & 12,6 & 11,1 & 7,9 \\
Switzerland & 4,8 & 3,1 & 1,9 \\
UK & 8,8 & 4,7 & 2,3 \\
United States & 15,5 & 6,7 & 3,2 \\
\hline
\end{tabular}

Source: OECD 2007, 89-90, table I.A1.3, Source: European Community Labour Force Survey, population aged 15 to 64 (data provided by Eurostat) except for Denmark (Population register $(1995,2000,2004)$. ISCDE refers to International Standard Classification of Education. ${ }^{7}$

\section{Political measures are needed to fix the problem}

The demand pressures that follow from the distorted age structure and labour mismatch are expected to be economically unbearable for national economies of most OECD countries, if annual immigration is not increased (OECD 2007, 30-32). The results would be seen across the society and the hardest hit would be; national economies, general employment and the core of the welfare states - public income transfers, and public services. The decreasing supply of skilled labour makes the problem worse for both the private, and the public sector (e.g. Valtiontilintarkastajat 2006, 69, 72; on availability of skilled workers in Finland by branch in 2005; ibid. 73-77).

\footnotetext{
${ }^{7}$ Post-industrialisation can be measured also in other ways, for instance by looking at a) how large a percentage of the labour force works in different branches of labour, b) what is the percentage of the GDP produced in those sectors: on Finland between 1860-2030, Tiainen et al. 1999, or c) how large is the demand for labour in different branches (Zorlu 2003).
} 
The obvious solution is to increase the supply of labour in accordance with the demand, but this is easier said than done. Political intervention is needed and this makes it rather difficult to implement. Put simply, there is need for two kinds of policies: firstly, employment and labour market policy to tackle the issues brought by labour mismatch, and secondly, population policy to manage ageing and the distorted age structure. I tandem, these political measures could save the OECD countries from some of the unemployment and problems in public finance that ageing and labour mismatch are about to bring.

Several simultaneous measures are suggested to be necessary, all designed to help the national economies and the people in the midst of declining working-age population and labour mismatch. The main suggested ways of increasing labour supply in the entire OECD are

-prolonging the average career, -increasing the productivity of work, -increasing the LFP rates of women, and -increasing demand-meeting foreign immigration (OECD 2007, Valtiontilintarkastajat 2006, 90).

The first three of these measures concern mobilising domestic labour resources. OECD nationals insist, sometimes fiercely, that this would be done before number four. Mobilisation would mean for example that unemployment rates and over-qualification rates would be decreased.

All these three measures are suggested to be needed in parallel because even if all domestic means were used and no mismatch existed, a shortage would remain in all OECD countries (OECD 2007, 30-32). The baby boom generations were simply that large and birth rates since then so low (United Nations 2006).

The mainstream population's resistance against immigration is a risk to rational societal policy against labour shortages. The reasons for the resistance may be many: the most common reason for anti-immigration attitudes in "advanced" economies is the belief that immigrants and immigration would be a socio-economic threat to natives (Pekkala 2005, 15).

The public resistance to immigration poses a threat to the possibility of nations to implementing policies to counteract labour shortage. Resistance to foreign immigration easily becomes resistance to the political means required to help the advanced economies in the challenge posed by the population transition and post-industrialism. Below, I discuss the Nordic situation. 


\section{The Nordic case}

As far as one can speak of one "Nordic case" - there is some variation in several variable values between the Nordic countries (e.g. age structure and LFP rates - the basic differences in relation to other OECD countries are that

- the large age cohorts were born a few years earlier than in the OECD countries in general, and that

- as far as labour force participation rates are concerned, the main unused labour resources are not women, but instead the elderly.

Another interesting feature is

- the great interdependence of Finnish and Swedish migration patterns.

In the Nordic countries, women's labour force participation rate is almost equal with that of men's. This is not the case in the OECD in general. In the Nordic countries, the LFP rates of women are relatively equal to those of men's (e.g. OECD 2007, 34), but in many other OECD countries, the situation is the opposite: throughout working age, men's LFP rates are higher than those of women.

This means that unlike in the OECD in general, in the Nordic countries, there is not much more unused labour resource among women, than men. The LFP rates depend substantially also on the country of birth - in the Nordic countries, native-born populations have higher LFP rates than foreign-born populations (ibid.). In both populations however, men's LFP rates are lower than those of women and thus it would seem that the main ways to increase labour supply and fight the labour shortages would be to extend working age, and increase the productivity of work in general.

However, gender equality in the Nordic countries is true only when one looks at the LFP rates. The situation changes when over-qualification is taken into account. Then, it can be seen that the Nordic countries have some unused female labour resource, one only has to look at over-qualification rates to find it. These rates show that women's labour market status is generally much lower than it should be with their education level. In the case of men, the situation is much better. General over-qualification of the population, but especially women is the case in the entire OECD. Over-qualified workers obviously form a rather large unused labour resource, and most of this resource is constituted by women. - also in the Nordic countries..

Over-qualification rates by gender are described in table 4 below. In the table, the data is divided also by country of birth (domestic / other), because country of birth affects the result greatly, currently some ten percent of the OECD countries' labour force is foreign-born (OECD 2007, 34). ${ }^{8}$ In the table, the percentage refers to how large a part of the employed population work in jobs that require less education than they have.

\footnotetext{
${ }^{8}$ In 1991-2004, approximately 12,4 percent of the officially employed in the OECD were foreign-born (OECD 2007, 63, table I.8). The data is based on different sources concerning different countries; census', household surveys, labour force surveys and issued work permits (ibid.).
} 
Table 2. Over-qualification rates by gender and country of birth in some OECD countries, 2003 and 2004 (OECD 2007, 139, table II.3).

\begin{tabular}{|lrr|rr|}
\hline & \multicolumn{2}{c}{ Foreign-born } & \multicolumn{2}{c|}{ Natives } \\
& Women & Men & Women & \multicolumn{1}{c|}{ Men } \\
Denmark & 19,7 & 17,5 & 10,5 & 10,4 \\
Finland & 26,2 & 12,2 & 18,8 & 9,7 \\
Norway & 25,1 & 16,1 & 10,6 & 6,3 \\
Sweden & 15,3 & 16,9 & 7,2 & 5,7 \\
Australia & 21,6 & 17,4 & 13,7 & 12,3 \\
Austria & 24,8 & 18,1 & 9,3 & 11,1 \\
Belgium & 24,6 & 19,4 & 17,7 & 13,8 \\
Canada & 27,6 & 23,2 & 21,7 & 20,9 \\
Czech Republic & 12,8 & 7,8 & 6,6 & 4 \\
France & 18,8 & 12,9 & 14,2 & 8,6 \\
Germany & 23,6 & 17,9 & 9,9 & 12,8 \\
Greece & 53,4 & 28,3 & 9 & 9 \\
Hungary & 10,5 & 9 & 7,3 & 5,5 \\
Ireland & 23,9 & 23,6 & 15,6 & 15,8 \\
Italy & 27,4 & 19,9 & 7,1 & 5,9 \\
Luxembourg & 14,1 & 5,6 & 3,2 & 3,6 \\
Mexico & 16,1 & 15,8 & 19,7 & 26,3 \\
Netherlands & 16,6 & 16,9 & 9,9 & 8,7 \\
New Zealand & 16 & 18,3 & 23,3 & 14,4 \\
Poland & 9,3 & 8,8 & 9,1 & 6,5 \\
Portugal & 16,2 & 17,5 & 8,9 & 6,5 \\
Slovak Republic & 27 & 22,2 & 27,9 & 26 \\
Spain & 47,6 & 38,8 & 24,4 & 24,1 \\
Switzerland & 13,8 & 11,4 & 7,6 & 12 \\
UK & 17 & 18,4 & 14,9 & 15,7 \\
United States & 17 & 19 & 11,2 & 15,5 \\
Turkey & 6,9 & 6,5 & 4,2 & 5,7 \\
\hline
\end{tabular}

Sources: European countries: European Community Labour Force Survey (data provided by Eurostat); 2005 for the Netherlands; United States: Current Population Survey March Supplement 2002; Australia, Canada, New Zealand, Poland and Slovak Republic: Population censuses, ca. 2001.9

The above table shows that in 2003 and 2004, in the Nordic countries (with the exception of Iceland on which no data was available), between 7.2 and 18.8 percent of native-born women were over-qualified by education, whereas this percentage within foreign-born women was almost double. Among men, there was also over-qualification, but the percentage was systematically higher in the case of women. Making better use, especially of women's labour is thus one measure to the Nordic countries when it comes to fighting labour shortages. This is a gender-specific issue which does not make it any easier for the politicians to find a way forward.

${ }^{9}$ Over-qualification by country of residence: ibid. 137 , table II. 2 
The main unmobilised labour resource in the Nordic countries is, however, people from the large elderly cohorts. How many of them could actually be employed, depends on how up-to-date their education is, and whether the working life they have left, renders it economically viable to invest in up-dating their education. Concerning some of these jobs elderly cohorts are a very large unused labour resource in the Nordic countries. For example in Finland, of all age groups until 2030 the elderly ones are suggested to be the largest but employment rates in them the lowest (Tiainen \& working group. 2007, 45 (fig. 3.3), 53, appendix table on p. 387).

Thus, in the Nordic countries, there are some untapped labour resources across both genders, in all age groups and among both natives and immigrants. The point I have sought to make in this paper, is that even though some demand pressures can be handled by mobilising them, this will not suffice because demand would still be larger than supply. On top of there is the skills mismatch: a fair share of the working-age people are not employed, or are over-qualified. In other words the existing workforce is not used as efficiently as possible.

\section{Conclusion: The Nordic challenge}

\section{The need for more labour immigration and better mobilisation of the labour resources}

Starting around 2010 the "advanced" economies of the world are likely to face labour shortages that are not caused by economic fluctuations. The United nations (2002), the Eurostat (2006a; 2006b) and the OECD (2007) project that the size of the workingage population will decrease extensively between 2005 and 2050. This is caused by population ageing. As the working-age population reaches retirement age, the number of the elderly $(55+)$ increases approximately by the same numbers. The size of the working-age population is projected to become too small to fulfil the demand for pensions and elderly care. In public finance of these countries this shows in the dependency ratios increase to economically problematic levels.

This problem is made more severe by the working-age population's labour force not being used efficiently. In the OECD countries, there exists some mismatch between the supply of and demand for labour. This is shown by the fact that qualified people are either unemployed or over-qualified, i.e. work in jobs that are not commensurate with their education (OECD 2007).

There also exist unused labour resources in the Nordic countries that can be mobilised as a partial solution to demand pressures. Unused labour exists throughout all age groups, across both genders, and among both natives and immigrants. Most of the unused labour resources can be found among people who are over 55 years but still under the official retirement age (data from OECD 2007, 30-32). A large percentage 
of the employed, especially in the case of women, are over-qualified. Like the OECD $(2007,31)$ puts it, "there exist in every [OECD] country sources of unutilised labour supply that can be mobilised in response to demand pressures". Due to women's high LFP rates in the Nordic countries unused labour resources are not as large as in the OECD in general (OECD 2007, 34).

However governments of the Nordic countries are also worried about how labour mmismatch decreases labour supply in addition to ageing. For example the Finnish State Treasurer's report goes that "it is primary importance that the demand for and supply of labour meet in an appropriate way" (Valtiontilintarkastajat 2006, 69). ${ }^{10}$

The policy implication could be that unused labour resources should be mobilised. The risk of not mobilising would seem to be that macroeconomic problems that would decrease the welfare states' capacity to fund welfare benefits and provide welfare services (i.e. Finland: Valtiontilintarkastajat 2006, 30-36).

This radically reduced labour supply would bring about labour shortages of all types: branch-wise, seasonal and regional. Avoiding the problem calls for determined and effective policies that increase the supply of the demanded kinds of labour when the baby boomers exit working age. To complement domestic means, foreign labour is also needed to fill the gap in labour supply. A major problem in the OECD is that immigration is necessary to increase labour supply and balance the age structure; this measure is often resisted by natives due to the unfounded belief that immigrants would threaten natives' employment and salaries (Pekkala 2005, 15) The European Union has emphasised that also discrimination on different grounds decreases labour supply significantly. ${ }^{11}$

\footnotetext{
${ }^{10}$ Translated from Finnish by the author.

11 "Evidence suggests that each year millions of people living in Europe experience discrimination on the basis of [different discrimination grounds]" (European Commission 2006, 7). The EU has established legislation againt discrimination; firstly, the Racial Equality Directive (Council Directive 2000/43/EC of 29 June 2000 implementing the principle of equal treatment between persons irrespective of racial or ethnic origin) and the Employment Equality Directive (Council Directive 2000/78/EC of 27 November 2000 establishing a general framework for equal treatment in employment and occupation).
} 


\section{Sources}

Bell, Daniel. 1999. The coming of the post-industrial society. A venture in social forecasting. New York: Basic Books.

European Commission. 2002. Communication from the Commission to the Council and the European Parliament. Europe's response to World Ageing: promoting economic and social progress in an ageing world. A contribution of the European Commission to the 2nd World Assembly on Ageing. COM(2002) 143 final, Brussels, March 18, 2002.

European Commission. 2006. European Handbook on Equality Data. Luxembourg: Office for Official Publications of the European Communities. Available at http:// ec.europa.eu/employment_social/fundamental rights/pdf/pubst/stud/hb07 en.pdf (January 22, 2009). ${ }^{12}$

European Commission. 2007. Europe's demographic future. Facts and figures on challenges and opportunities. Brussels: European Commission, Directorate-General for Employment, Social Affairs and Equal Opportunities, Unit E.1.). Document drawn up on the basis of COM(2006)571 final, COM(2005)94 final and SEC(2007)638. Available at http://ec.europa.eu/employment_social/spsi/docs/social_situation/ demo report 2007 en.pdf (January 22, 2009).

Eurostat. 2006a. Statistics in focus, population and social conditions 3/2006: Longterm population projections on a national level. Available at http://epp.eurostat. ec.europa.eu/cache/ITY OFFPUB/KS-NK-06-003/EN/KS-NK-06-003-EN.PDF (January 22, 2009)

Eurostat. 2006b. Population projections 2004-2050. EU25 population rises until 2025, then falls. Working age population expected to decrease by 52 million by 2050 . Press release 48/2005, April 8, 2005.

Giddens, Anthony. 1997. Sociology (third ed.) Cambridge: Polity Press.

Karisto, Antti, Pentti Takala and Ilkka Haapoja. 1998. Matkalla nykyaikaan. Elintason, elämäntavan ja sosiaalipolitiikan muutos Suomessa. Helsinki: WSOY (Towards the present day. The change of the living standard, of the way of living and of social policy in Finland).

Knocke, Wuokko. 2000. Sweden: insiders outside the Trade-Union mainstream. In Penninx, Rinus \& Roosblad, Judith (2000, eds.) Trade unions, immigrants and immigration in Europe 1960-1993. A comparative study of the attitudes and actions of trade unions in seven West European countries. New York: Berghahn Books, $157-182$.

OECD. 2007. International migration outlook (SOPEMI 2007). Paris: OECD.

Pekkala, Sari. 2005. Economic impacts of immigration: a survey. Helsinki: Governmental institute for economic research (VATT), discussion papers 362.

Penninx, Rinus and Judith Roosblad. 2000. Conclusion. In Trade unions, immigrants and immigration in Europe 1960-1993. A comparative study of the attitudes and actions of trade unions in seven West European countries, edited by Rinus Penninx, and Judith Roosblad. New York: Berghahn Books, 213-224.

\footnotetext{
${ }^{12}$ Also available in French and in German from the same site. Manuscript written by Timo Makkonen.
} 
UNFPA, United Nations Population Fund. 1999. The state of the world population in 1999. Six billion: a time for choices. Available at http://www.unfpa.org/swp/1999/ index.htm (January 22, 2009).

Tiainen, Pekka. 2007. Työvoima 2025. Täystyöllisyys, korkea tuottavuus ja hyvät työpaikat hyvinvoinnin perustana työikäisen väestön vähentyessä (the labour force and welfare in ageing Finland. Helsinki: työministeriö (The Ministry of Labour). Available at http://www.mol.fi/mol/fi/99 pdf/fi/06 tyoministerio/06 julkaisut $/ 06$ tutkimus/tpt325.pdf (January 22, 2009).

United Nations. 2002. World Population Ageing: 1950-2050. United Nations Population Division, Department of Economic and Social affairs.

United Nations. 2006. World Population Prospects, the 2006 Revision. Figures available at http://www.un.org/esa/population/publications/wpp2006/wpp2006 ageing.pdf (January 22, 2009).

Valtiontilintarkastajat. 2006. Valtiontilintarkastajien vuosikertomus 2006. Helsinki: Eduskunta. [The State Treasurer's annual report 2006].

Zorlu, Aslan. 2003. Absorption of immigrants in European labour markets. The Netherlands, United Kingdom and Norway. Amsterdam: Thela Thesis. 